Scientific Review - Engineering and Environmental Sciences (2018), 27 (3), 280-290

Sci. Rev. Eng. Env. Sci. (2018), 27 (3)

Przegląd Naukowy - Inżynieria i Kształtowanie Środowiska (2018), 27 (3), 280-290

Prz. Nauk. Inż. Kszt. Środ. (2018), 27 (3)

http://iks.pn.sggw.pl

DOI 10.22630/PNIKS.2018.27.3.27

Hubert ANYSZ, Wojciech ROGALA

Faculty of Civil Engineering, Warsaw University of Technology

\title{
The control of the mass of an aggregates deliveries and its impact on the effectiveness of earthworks execution
}

Key words: aggregate supplies control, earthworks effectiveness, statistical weight control, determination of the sample size, determination the mean on the basis of a sample, the effectiveness of aggregate supplies

\section{Introduction}

The construction project is considered as successful as it finishes within planned schedule and budget (Skorupka, Kuchta \& Górski, 2012). Particularly in case of linear structures and water and sewage networks, the bulk materials are among the most important positions in the project budget, which can reach even $20 \%$ of total costs (Ośrodek Wdrożeń Ekonomiczno-Organizacyjnych Budownictwa "Promocja", 2015). Controlling the deliveries of aggregates under construction conditions is problematic due to the difficulty of assessing the quantity of products that are not packaged in countable units. Human resources problems of these days, as well as shortening construction works time, often makes precise control of the weight of all transports impossible. Due to that facts, inspection of transports is usually limited only to visual assessment and a control of documents. The lack of reliable control of deliveries can effect in a lower transport efficiency and large discrepancies between ordered and delivered amount of aggregates. Lower transport efficiency contributes to its cost overestimation (Sobotka, Radziszewska-Zielina, Plebankiewicz \& Kowalik, 2014) and environmental pollution (Pawłowska, 2018).

The profit is necessary for contractors business. It allows to survive during economic downturn, as well as develop while economics is in excellent condition (Anysz, 2017). Taking into account the average gross profit of construction companies of 6-7\% (Deloitte, 2017), such discrepancies can influence not only project success but also contractor financial condition.

The weight control of all incoming (and next, outgoing) dump trucks is affordable only for a limited number of 
companies. The easiest method of controlling random trucks based on determining the mean of transported mass can be not enough effective, as it does not answer the question what is the optimal number of samples to be inspected. It does not answer what is the estimation error in that method as well, what can be the reason for questioning its result by a supplier.

The research aims to propose a tool, which allows pointing the optimal number of trucks to be inspected. The method based on statistics allows to determine the average weight of the transport with specified probability and estimation error, so the total weight of supplied goods can be estimated too.

\section{Research method}

Usually, the amount of loose material on a truck is estimated on basis of a loading machine parameter (digger, loader, belt conveyor) e.g. a bucket volume. It happens very rarely to control the mass of deliveries on construction site, especially if linear construction works are considered. The visual method of evaluating the loose material volume is prone to large discrepancies as:

- natural materials are considered, which are not homogenous;

- a differential in fractions of the material at respective depths of the spoil may occur;

- variable weather conditions cause the differences in loose materials density.

The population is defined as a number of homogenous dump trucks entering a building site. The weight of aggregates delivered in a single turn can be considered as normally distributed on following conditions:

- all means of transport have the same capacity;

- all deliveries are made by single company;

- the loading method is the same and deliveries are made from the same mine;

- all machine operators involved in the delivery process (loading, transporting, acceptance) have clear intentions.

All conditions specified above have to be met, otherwise, deliveries have to be divided into separate, smaller homogenous populations, which requires individual calculations for them. These conditions cause, that even on large construction sites the homogenous populations might not be significant.

Depending on quantity of aggregates to be delivered, construction site surrounding, distance to loading place and logistics on construction site, the load capacity of typically used means of transport used for aggregates vary from 8 up to 26 t. Deliveries of underloaded trucks result in a lower total weight of material delivered, lower project profitability and lower transport efficiency. Deliveries of overloaded trucks are desirable for a contractor but may result in penalties for exceeding capacity and decreases supplier efficiency.

Vehicles with capacity of $18 \mathrm{t}$ have been used for calculation. To check versatility of the tool, 3 types of construction site have been analyzed (Table 1).

Authors expect the large standard deviation under construction conditions, even if considering of carelessness and 
TABLE 1. Aggregates deliveries, analyzed in the research

\begin{tabular}{|c|c|c|c|c|c|}
\hline $\begin{array}{c}\text { Length } \\
\text { of roadworks } \\
{[\mathrm{m}]}\end{array}$ & $\begin{array}{c}\text { Width } \\
\text { of roadworks } \\
{[\mathrm{m}]}\end{array}$ & $\begin{array}{c}\text { Thickness } \\
\text { of aggregates } \\
\text { layer } \\
{[\mathrm{m}]}\end{array}$ & $\begin{array}{c}\text { Bulk density } \\
\text { of aggregates } \\
{\left[\mathrm{kg} \cdot \mathrm{m}^{-3}\right]}\end{array}$ & $\begin{array}{c}\text { Compact- } \\
\text { ness }\end{array}$ & $\begin{array}{c}\text { Estimated quan- } \\
\text { tity of 18-tons } \\
\text { transport means }\end{array}$ \\
\hline 1800 & \multirow{2}{*}{20} & 0.15 & 1.65 & 0.98 & 500 \\
\hline 5000 & & & & & 1400 \\
\hline 10000 & & & & & 2800 \\
\hline
\end{tabular}

unclear intentions of the supplier are omitted. Data rounded to $10 \mathrm{~kg}$ for each construction sites have been drawn using 3 methods:

- supplier S1 - random data from population with standard distribution $(\sigma=240 \mathrm{~kg}, \mu=17,950 \mathrm{~kg})$;

- supplier S2 - random data from population with standard distribution $(\sigma=480 \mathrm{~kg}, \mu=17,750 \mathrm{~kg})$;

- supplier S3 - random data, drawn from intervals $(0.93 \cdot 18,000 ; 18,000)$ and $(1,800 ; 1.03 \cdot 18,000)$ with 37 and $63 \%$ probability respectively.

The process of determining the required deliveries to be inspected have to be divided into 3 steps. In described case standard deviation of population $(\sigma)$ and mean of population $(\mu)$ is unknown. Thus in the first step sample standard deviation $(S)$ and sample mean $(\bar{X})$ have to be determined after initial testing of at least 30 samples. On the basis of $\mathrm{S}$ and $\bar{X}$ obtained from the test, in the second step the rest of required trucks to be inspected have to be determined under assumed confidence level and estimation error conditions. The last step includes controlling the appointed dump trucks. On the basis of this result, the mean and estimated sum of deliveries for the whole population have to be calculated.

Due to high restrictions on the homogeneity of the population authors decid- ed to include finite-population correction factor in confidence level formula.

The finite-population correction factor $(f p c)$ is expressed as follows (Aczel, 1993):

$f p c=\sqrt{\frac{N-n}{N-1}}$

where:

$N$ - population size;

$n$ - sample size.

The confidence interval for a mean with unknown standard deviation (Aczel, 1993) with finite-population correction factor (1) is expressed as follows:

$P\left\{\bar{X}-t_{\frac{\alpha}{2}} \frac{S}{\sqrt{n}} \sqrt{\frac{N-n}{N-1}} ; \bar{X}+t_{\frac{\alpha}{2}} \frac{S}{\sqrt{n}} \sqrt{\frac{N-n}{N-1}}\right\}=1-\alpha$

where:

$\bar{X}$ - mean resulted from initial testing;

$\mathrm{S}$ - standard deviation of initially tested samples;

$t_{\frac{\alpha}{2}}-$ critical value of $t$-distribution for assumed confidence level $1-\alpha$ (the recommended value $-95 \%$ ), for $n-1$ degrees of freedom).

To limit possible error to a specific level, authors decided to introduce maximum estimation error, which allows lim- 
iting the inaccuracy of the mean to value defined in kilograms.

Due to (2) the estimation error $(\tau)$ satisfies the following inequality:

$t_{\frac{\alpha}{2}} \frac{S}{\sqrt{n}} \sqrt{\frac{N-n}{N-1}} \leq \tau$

From (3) the minimum number of required samples to be tested:

$$
n \geq \frac{N \cdot t_{\frac{\alpha}{2}}^{2} \cdot S^{2}}{\tau^{2} \cdot(N-1)+t_{\frac{\alpha}{2}}^{2} \cdot S^{2}}
$$

The estimated mean of the population (with assumed estimation error and confidence level):

$\bar{X}=\frac{\sum_{i=1}^{n} m_{i}}{n} \pm \tau$

where:

$m_{i}$ - mass of aggregates delivered by single dump truck $i(i=1,2,3 \ldots, n)[\mathrm{kg}]$; $\tau$ - estimation error of the mean $[\mathrm{kg}]$.
Example calculation based on Excel tool. Authors have developed a tool, which uses the equations mentioned above (Fig. 1).

The first sheet "Data" is developed for entering data obtained from initial 30 sample test. Second sheet "Number of transports" is used for determining the required number of dump trucks to be inspected under assumed confidence level and estimation error conditions.

The lower estimation error is assumed, the more dump trucks should be weighted. It is possible to find the optimum estimation error (Fig. 2), minimizing the total cost (c) given by the formula:

$c(\tau)=\tau \cdot N \cdot p_{a}+n \cdot p_{w}$

where:

$p_{a}$ - price of aggregates $\left[\mathrm{PLN} \cdot \mathrm{kg}^{-1}\right]$;

$n$ - number of required samples to be tested, determined from (3), depended on $\tau$;

$p_{w}-$ price of single truck weighting [PLN].

On the basis of 9 variants described in Table 2 and current prices of loose materials, the optimal estimation error is usually between 30 and $200 \mathrm{~kg}$.

\begin{tabular}{|l|c|}
\hline Total amount of deliveries & 2800 \\
\hline Confidence level & 0,95 \\
\hline initial sample & 30 \\
\hline Mean of initial sample & 17798,00 \\
\hline Standard deviation of initial sample & 575,78 \\
\hline Estimation error [kpl & 100 \\
\hline \hline Number of trucks to cantrol & 131 \\
\hline
\end{tabular}

Appoint the number of trucks which should be inspected

FIGURE 1. Screenshot of "Number of transports" sheet used for the required sample calculation 


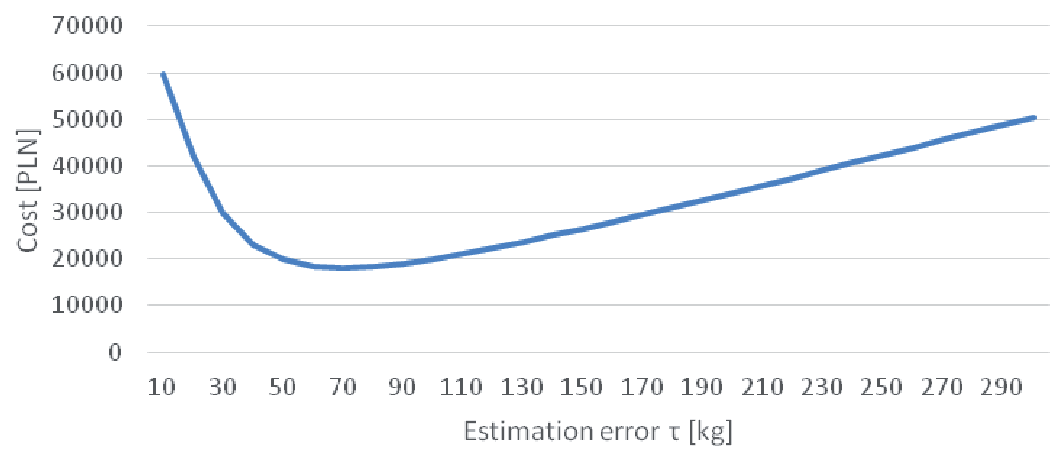

FIGURE 2. The optimum error appointment (supplier S2, $N=2,800, p_{a}=60 \mathrm{PLN} \cdot \mathrm{t}^{-1}, p_{w}=25 \mathrm{PLN}$ )

TABLE 2. Analyzed populations (unknown in real case)

\begin{tabular}{|c|c|c|c|c|}
\hline \multirow{3}{*}{ Supplier } & \multicolumn{4}{|c|}{ Population } \\
\cline { 2 - 5 } & $\begin{array}{c}\text { quantity } \\
{[\mathrm{pcs}]}\end{array}$ & $\begin{array}{c}\mu \\
{[\mathrm{kg}]}\end{array}$ & $\begin{array}{c}\sigma \\
{[\mathrm{kg}]}\end{array}$ & $\begin{array}{c}\text { sum } \\
{[\mathrm{t}]}\end{array}$ \\
\hline \multirow{3}{*}{ S1 } & 500 & 17939 & 236.92 & 8970 \\
\cline { 2 - 5 } & 1400 & 17946 & 237.16 & 25124 \\
\cline { 2 - 5 } & 2800 & 17944 & 237.42 & 50243 \\
\hline \multirow{3}{*}{ S2 } & 500 & 17765 & 506.52 & 8883 \\
\cline { 2 - 5 } & 1400 & 17749 & 475.81 & 24848 \\
\hline \multirow{3}{*}{ S3 } & 2800 & 17758 & 477.46 & 49722 \\
\cline { 2 - 5 } & 500 & 17675 & 528.40 & 8838 \\
\cline { 2 - 5 } & 1400 & 17687 & 533.76 & 24761 \\
\hline
\end{tabular}

The last sheet "The result" is to enter the missing data (the rest of transports to control) and estimate the total sum of deliveries. During the research, 9 variants presented in Table 2 have been analyzed. The results of tests are shown in Table 3 .

\section{Results}

The initial control of transport mass, based on 30-element sample, allows evaluating the quality of supplier. Depending on the standard deviation and the mean it is possible to conclude if the supplier can be considered as reliable. Then earthworks quantity survey done on the basis of deliveries total volume should confirm the result. The high value of standard deviation can also lead to search for reasons of heterogeneity of populations. It can be a milestone, after which decision on further cooperation or keeping contract terms unchanged can be made. Nevertheless, the supplier assessment based on initial test results distribution can be confusing. Despite the fact, that deliveries from supplier 3 
TABLE 3. The results of the test

\begin{tabular}{|c|c|c|c|c|c|c|c|c|}
\hline \multirow[b]{2}{*}{ Supplier } & \multicolumn{2}{|c|}{ Initial test } & \multicolumn{6}{|c|}{ Appointed test } \\
\hline & $\begin{array}{c}\bar{X} \\
{[\mathrm{~kg}]}\end{array}$ & $\begin{array}{c}S \\
{[\mathrm{~kg}]}\end{array}$ & $\begin{array}{c}\text { trucks } \\
{[\mathrm{pcs}]}\end{array}$ & $\begin{array}{c}\tau \\
{[\mathrm{kg}]}\end{array}$ & $\begin{array}{c}X \\
{[\mathrm{~kg}]}\end{array}$ & $\begin{array}{c}S \\
{[\mathrm{~kg}]}\end{array}$ & $\begin{array}{l}\text { estimated } \\
\text { sum } \\
{[\mathrm{t}]}\end{array}$ & $\begin{array}{l}\tau \text { related to } \\
\text { population } \\
{[\mathrm{t}]}\end{array}$ \\
\hline \multirow{3}{*}{ S1 } & \multirow{3}{*}{17897} & \multirow{3}{*}{259.68} & 131 & \multirow{3}{*}{40} & 17939 & 244.82 & 8970 & 20 \\
\hline & & & 157 & & 17945 & 240.76 & 25123 & 56 \\
\hline & & & 166 & & 17945 & 236.52 & 50246 & 112 \\
\hline \multirow{3}{*}{ S2 } & \multirow{3}{*}{17798} & \multirow{3}{*}{575.78} & 109 & \multirow{3}{*}{100} & 17764 & 573.80 & 8882 & 50 \\
\hline & & & 127 & & 17738 & 569.58 & 24833 & 140 \\
\hline & & & 133 & & 17750 & 571.38 & 49700 & 280 \\
\hline \multirow{3}{*}{ S3 } & \multirow{3}{*}{17570} & \multirow{3}{*}{502.85} & 88 & \multirow{3}{*}{100} & 17736 & 511.54 & 8868 & 50 \\
\hline & & & 99 & & 17708 & 506.56 & 24791 & 140 \\
\hline & & & 102 & & 17707 & 499.89 & 49580 & 280 \\
\hline
\end{tabular}

are not normally distributed, the visual evaluation based on 30 tests can lead to that conclusion.

As the Kołomogorov-Smirnov test cannot be applied according to unknown distribution parameters of the population (Kot, Jakubowski \& Sokołowski, 2011), Shapiro-Wilk test (Rabiej, 2012) was applied. It is widely used test (Słowik \& Rogalska, 2013; Kępniak \& Woyciechowski, 2015), as it is recognized as a powerful one (Kot et al., 2011). For all suppliers, the test shows $p>0.05$. Together with visual evaluation of histograms (Statsoft, 2005), samples taken from each supplier can be treated as taken from the population of the normal distribution. The histogram of the sample taken from supplier 2 seems the weakest matching the curve but on the still moderate level of matching the normal distribution (Fig. 3).

Results of test mentioned above are summarized in Table 4. The same evaluation was done for the samples of the size calculated for the population 500, 1,400 and 2,800 deliveries, for each supplier. It is to emphasize that, Shapiro-Wilk test and visual evaluation excluded supplier 3 from normal distributions (for the sample size bigger than 30 elements).

At the same time fitting level (visual and $p$ value) for suppliers 1 and 2 has been improved much (Fig. 4.)

\section{Hypothesis testing about the population means}

When the standard deviation of the population is unknown, but it is known for the sample, the t-Student test can be applied. The other assumption, claimed by many statisticians (Aczel, 1993), is normality of the population. The hypothesis to check is: if the mean in the population $(\mu)$ is higher than mean from the sample increased by assumed error (so-called one side test). For instance, for the supplier 1 and population 500 deliveries, we can write:

$$
\begin{aligned}
& H_{0}: \mu \geq 17,979 \\
& H_{1}: \mu<17,979
\end{aligned}
$$



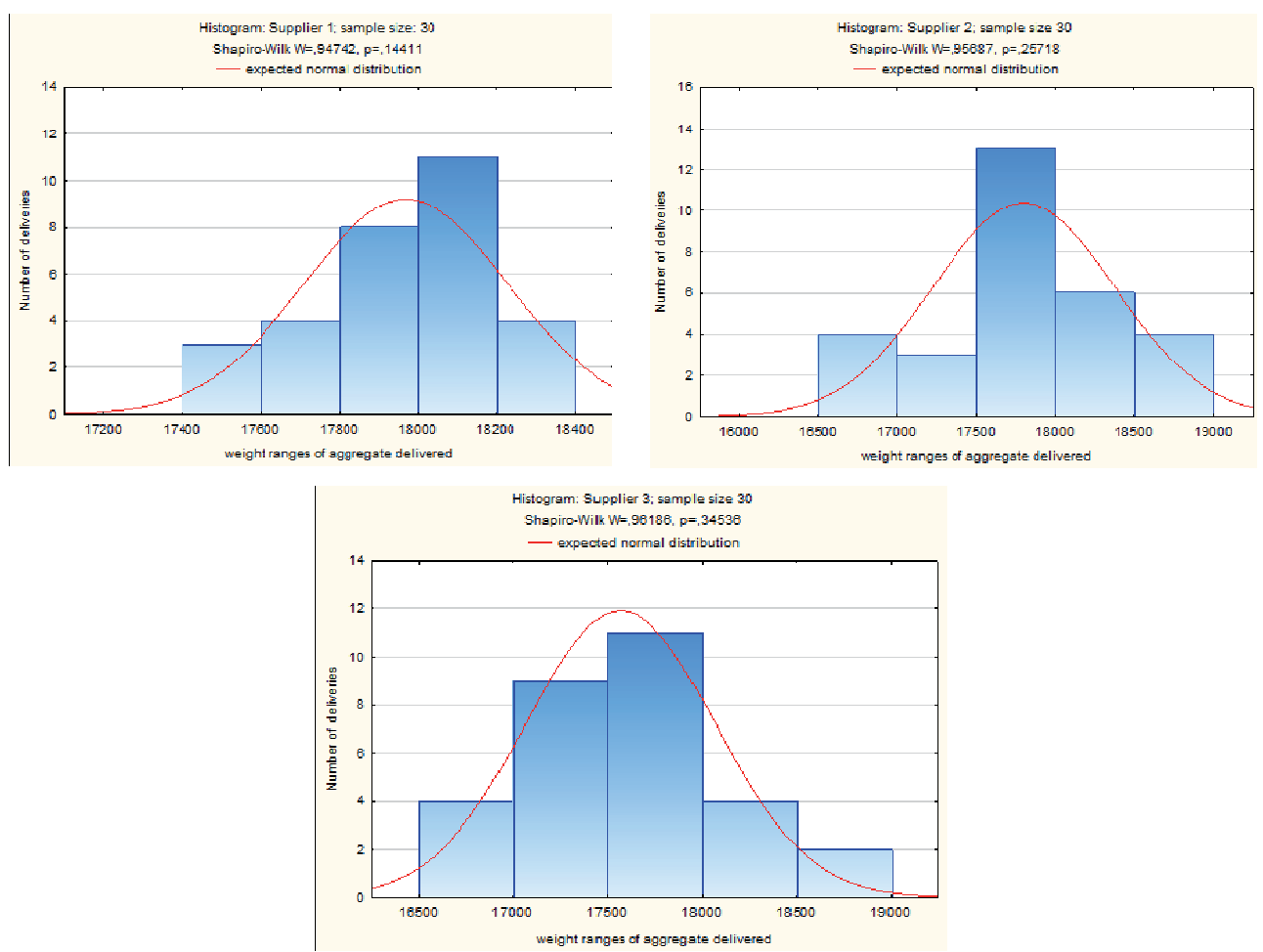

FIGURE 3. Histograms and fitting the normal distributions of 30-element sample for each supplier

TABLE 4. The evaluation of initial tests distribution

\begin{tabular}{|c|c|c|c|c|c|}
\hline \multirow{2}{*}{ Supplier } & \multirow{2}{*}{$\begin{array}{l}\text { sample } \\
\text { size }\end{array}$} & \multicolumn{2}{|c|}{ Shapiro-Wilk tests } & \multirow{2}{*}{$\begin{array}{c}\text { Visual evaluation } \\
\text { of conformity with the } \\
\text { normal distribution }\end{array}$} & \multirow{2}{*}{$\begin{array}{l}\text { Evaluation of confor } \\
\text { mity with the normal } \\
\text { distribution }\end{array}$} \\
\hline & & $W$ & $p$ & & \\
\hline 1 & 30 & 0.947 & $0.144>0.05$ & moderate & yes \\
\hline 2 & 30 & 0.957 & $0.257>0.05$ & moderate & yes \\
\hline 3 & 30 & 0.962 & $0.345>0.05$ & moderate & yes \\
\hline
\end{tabular}

The alternative hypothesis is that the average weight of a single delivery in the whole population of them is lower than $17,979 \mathrm{~kg}$. The $t$ value can be calculated using the formula:

$t=\frac{\bar{X}-\mu}{S / \sqrt{n}}$
As the $t$ value calculated for all of the suppliers is lower than $t$ read from tables, alternative hypothesis $H_{1}$ should be accepted. It means that the mean weight in the all 9 cases, with $95 \%$ confidence is lower than the sample mean plus assumed error. It is to remember, that calculating the size of sample, the levels of 

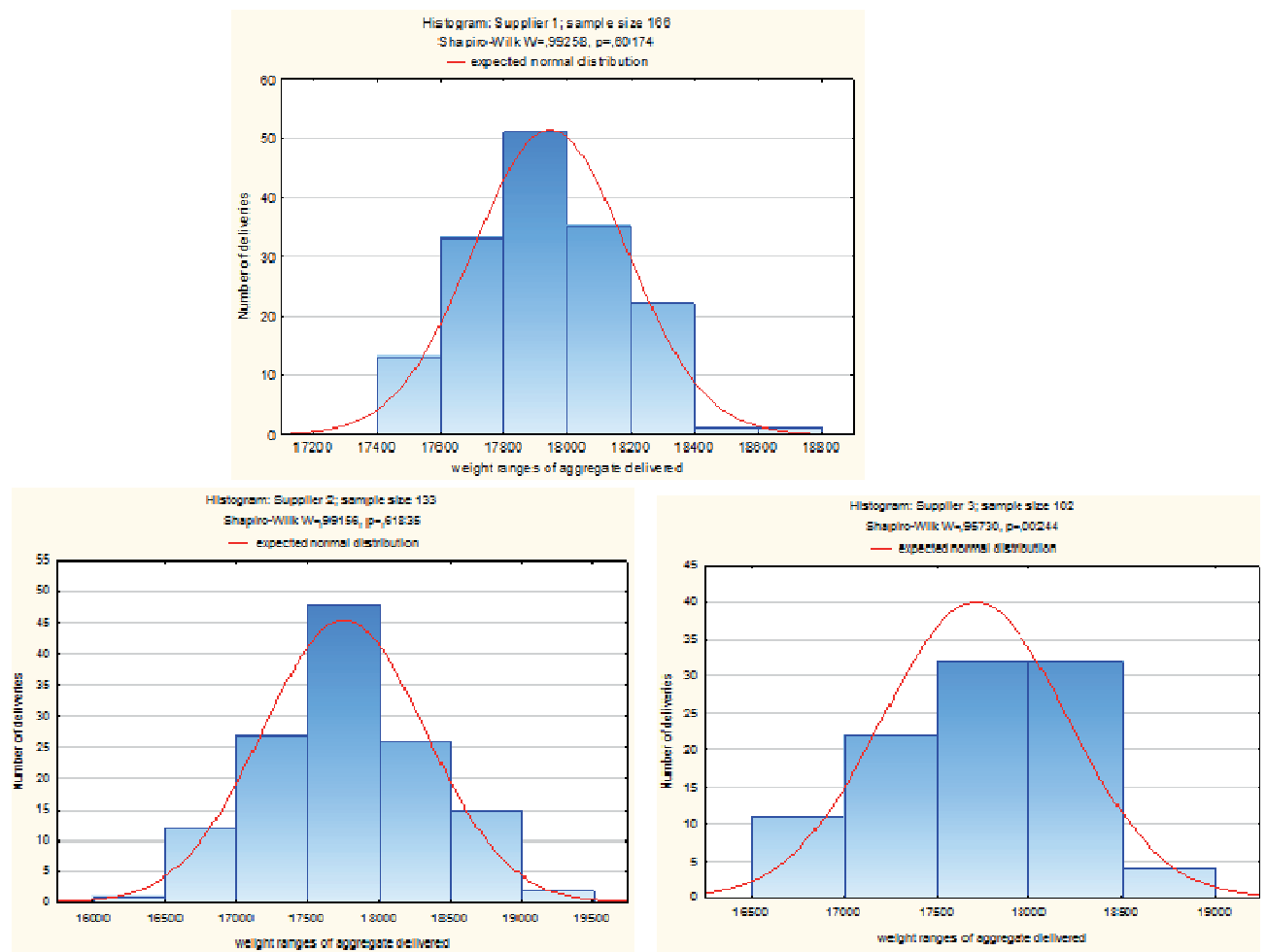

FIGURE 4. Histograms and fitting the normal distributions of samples relevant for 2,800 population for each supplier

TABLE 5. Results of t-test (tables of $t_{0.05}$ values for one side test taken from (Lissowski, Haman \& Jasiński, 2011)

\begin{tabular}{|l|c|c|c|c|c|c|c|c|c|}
\hline Item & \multicolumn{3}{|c|}{ Supplier 1 } & \multicolumn{3}{c|}{ Supplier 2 } & \multicolumn{3}{c|}{ Supplier 3 } \\
\hline Population & 500 & 1400 & 2800 & 500 & 1400 & 2800 & 500 & 1400 & 2800 \\
\hline Sample size & 131 & 157 & 166 & 109 & 127 & 133 & 88 & 99 & 102 \\
\hline$d f$ & 130 & 156 & 165 & 108 & 126 & 132 & 87 & 98 & 101 \\
\hline$t$ read from tables & -1.66 & -1.66 & -1.66 & -1.66 & -1.66 & -1.66 & -1.66 & -1.66 & -1.66 \\
\hline$t$ calculated & -1.870 & -2.082 & -2.179 & -1.820 & -1.979 & -2.018 & -1.834 & -1.964 & -2.020 \\
\hline
\end{tabular}

error were assumed (40 $\mathrm{kg}$ for supplier 1 and $100 \mathrm{~kg}$ for suppliers 2 and 3). As it is shown in Table 6 that there is no base to reject another hypothesis $H_{0}$ that mean of the population is equal or higher than the sample mean minus assumed error for all suppliers.
It was confirmed by hypothesis testing that using the created excel tool for estimating the population mean on the assumed confidence level 95\% were calculated correctly. 
TABLE 6. Results of t-test for $\mathrm{H}_{0}: \mu \geq$ the sample mean minus assumed error, calculated for all the suppliers

\begin{tabular}{|l|c|c|c|c|c|c|c|c|c|}
\hline Item & \multicolumn{3}{|c|}{ Supplier 1 } & \multicolumn{3}{c|}{ Supplier 2 } & \multicolumn{3}{c|}{ Supplier 3 } \\
\hline Population & 500 & 1400 & 2800 & 500 & 1400 & 2800 & 500 & 1400 & 2800 \\
\hline Sample size & 131 & 157 & 166 & 109 & 127 & 133 & 88 & 99 & 102 \\
\hline$d f$ & 130 & 156 & 165 & 108 & 126 & 132 & 87 & 98 & 101 \\
\hline$t$ read from tables & -1.66 & -1.66 & -1.66 & -1.66 & -1.66 & -1.66 & -1.66 & -1.66 & -1.66 \\
\hline$t$ calculated & 1.870 & 2.082 & 2.179 & 1.820 & 1.979 & 2.018 & 1.834 & 1.964 & 2.020 \\
\hline
\end{tabular}

\section{Summary and discussion}

The results of calculations show the correctness of assumed method for calculation (Table 3). The mean weight of transport for suppliers 1 and 2 is included within assumed accuracy.

Although supplies S3 cannot be considered as normally distributed, the mean weight of the transport is determined correctly.

The distribution of final testing results can answer much more questions. If distribution cannot be evaluated as normal, either the population was incorrectly assumed as homogenous, or the mass of transports have been manipulated on purpose. To evaluate the finite-population factor influence, 10,000 simulation of deliveries for each nine variants have been made. The result of the simulation is presented in Table 7.

The last column of Table 7 shows the percent of deliveries, where the estimated mean on the basis of the appointed

TABLE 7. Simulation of 10,000 deliveries per 9 variants

\begin{tabular}{|c|c|c|c|c|c|}
\hline \multirow{4}{*}{ Supplier } & \multicolumn{2}{|c|}{ Population } & \multicolumn{3}{c|}{ Appointed test } \\
\cline { 2 - 6 } & $\begin{array}{c}\text { quantity } \\
{[\mathrm{pcs}]}\end{array}$ & $\begin{array}{c}\mu \\
{[\mathrm{kg}]}\end{array}$ & $\begin{array}{c}\text { trucks averaged } \\
{[\mathrm{pcs}]}\end{array}$ & $\begin{array}{c}\bar{X} \\
{[\mathrm{~kg}]}\end{array}$ & $\begin{array}{c}\text { deliveries with estima- } \\
\text { tion error exceeded [\%] }\end{array}$ \\
\hline \multirow{5}{*}{ S1 } & 500 & 17950.0 & 114 & 17950.0 & 5.03 \\
\cline { 2 - 6 } & 1400 & 17950.2 & 134 & 17950.0 & 5.00 \\
\cline { 2 - 6 } & 2800 & 17949.4 & 141 & 17950.0 & 5.05 \\
\cline { 2 - 6 } & infinity* & 17950.3 & 150 & 17950.1 & 2.35 \\
\hline \multirow{5}{*}{ S2 } & 500 & 17749.8 & 79 & 17749.7 & 4.99 \\
\cline { 2 - 6 } & 1400 & 17749.5 & 89 & 17750.0 & 4.93 \\
\cline { 2 - 6 } & 2800 & 17749.8 & 92 & 17750.3 & 4.97 \\
\hline \multirow{4}{*}{ S3 } & infinity* & 17749.8 & 95 & 17749.9 & 3.57 \\
\cline { 2 - 6 } & 500 & 17704.2 & 95 & 17702.9 & 4.52 \\
\cline { 2 - 6 } & 1400 & 17704.3 & 108 & 17702.9 & 5.07 \\
\cline { 2 - 6 } & 2800 & 17704.1 & 112 & 17703.0 & 4.80 \\
\hline
\end{tabular}

*Calculation without finite-population factor. 
number of weight controls have exceeded the estimation error.

In cases where finite-population factor have been used, this value is very close to assumed significance level $\alpha=5 \%$. This proves that excluding the finite-population factor in calculation results in the non-optimal appointed number of controls, as deliveries which exceed the estimation error not correspond with assumed significance level. What is surprising, although the distribution of supplies S3 is not normal, the mean weight calculated on the basis of appointed trucks number and significance level turned out to be correct.

\section{Conclusions}

The insufficient quality control is an important and up-to-date problem of construction projects (Deszcz, 2017). The statistics can be used for determining the optimal number of trucks, which mass should be verified to estimate the total mass of supplied aggregates. What is more, it allows optimizing the controlling costs of deliveries. The mean appointed on the basis of statistical test can be used to evaluate the total sum of deliveries. The proposed method can contribute to the project success as it reduces the risk of payment for unrealized deliveries.

Nevertheless before initial testing a research should be done, in order to find the homogenous population of transports. The calculation should be supplemented by visual assessment of distribution of controlled transports.

The contract terms can affect much the project success (Czaczkowski, 2013).
The proposed tool and its assumptions can be the base of a settlement between contractor and aggregates supplier described in contract terms. The method can be used as well by a supplier to optimize the usage of transport means. Many surveyors proved, that proper choice of contractor or subcontractor affects the effectiveness of the project (Leśniak, Plebankiewicz \& Zima, 2012; Ibadov, 2015; Biruk, Jaśkowski \& Czarnigowska, 2017). The described case proves, that also the proper choice of materials supplier can influence the cost of the project, so affects its effectiveness as well.

\section{References}

Aczel, A.D. (1993). Complete Business Statistics. Chicago: Irwin Professional Publishing.

Anysz, H. (2017). The profit as in-company evaluation of the construction site effectiveness. MATEC Web of Conferences, 117, 1-6. DOI: $10.1051 /$ matecconf/201711700009

Biruk, S., Jaśkowski, P. \& Czarnigowska, A. (2017). Minimizing Project Cost by Integrating Subcontractor Selection Decision with Scheduling. IOP Conference Series: Material Science and Engineering, 245, 072007. doi: 10.1088/1757-899X/245/7/072007

Czaczkowski, W. (2013). Standaryzacja procedur kontraktowych w umowach o roboty budowlane. Scientific Review - Engineering and Environmental Sciences, 22(1), 98-104.

Deszcz, J. (2017). Planowanie jakości w realizacji przedsięwzięć budowlanych $\mathrm{z}$ zastosowaniem ,risk-based thinking”. Scientific Review - Engineering and Environmental Sciences, 26(2), 258-265. doi: 10.22630/ PNIKS.2017.26.2.25

Deloitte (2017). Polskie spótki budowlane 2017 - najważniejsi gracze, kluczowe czynniki wzrostu i perspektywy rozwoju branży.

Ibadov, N. (2015). Contractor selection for construction project, with the use of fuzzy 
preference relation. Procedia Engineering, $111,317-323$

Kępniak, M. \& Woyciechowski, P. (2015). Statistical analysis of relation between compressive and tensile/flexural strenght of high perfomance concrete. Archives of Civil Engineering, 57(4/2), DOI: 10.1515/ace-2015-0110

Kot, S.M., Jakubowski, J. \& Sokołowski, A. (2011). Statystyka. Warszawa: Diffin.

Leśniak, A., Plebankiewicz, E. \& Zima, K. (2012). Design and build procurement system - contractor selection. Archives of Civil Engineering, 57(4), 463-476. doi: 10.2478/ v.10169-012-0025-9

Lissowski, G., Haman, J. \& Jasiński, M. (2011). Podstawy statystyki dla socjologów. Wnioskowanie statystyczne. Vol. 3. Warszawa: Wydawnictwo Naukowe Scholar.

Ośrodek Wdrożeń Ekonomiczno-Organizacyjnych Budownictwa „Promocja” - OWEOB (2015). Biuletyn Cen Obiektów Budowlanych $B C O, c z$. II - obiekty inżynieryjne, 15.

Pawłowska, B. (2018). Koszty zewnętrzne transportu w Polsce. Scientific Review - Engineering and Environmental Sciences, 27(1), 28-41. doi: 10.22630/PNIKS.2018.27.1.4

Rabiej, M. (2012). Statystyka z programem Statistica. Gliwice: Helion.

Skorupka, D., Kuchta, D. \& Górski, M. (2012). Zarzadzanie ryzykiem w projekcie. Wrocław: WSOWL.

Słowik, M. \& Rogalska, M. (2013). The statistical analysis of design methods efficiency in determining shear capacity of reinforced concrete beams. In D. Novak \& M. Vorechovsky (Eds.) Proceedings of the $11^{\text {th }}$ International Probabilistic Workshop (pp. 373-384). Brno: Brno University of Technology, Faculty of Civil Engineering, Institute of Structural Mechanics. Retrieved from: http://www.stm. fce.vutbr.cz/ipw/ipw_static/stm.fce.vutbr. cz/ipw11_data/Proceedings_IPW11.pdf.

Sobotka, A., Radziszewska-Zielina, E., Plebankiewicz, E. i Kowalik, M. (2014). Realizacja robót ziemnych w opinii wykonawców budowlanych. Scientific Review - Engineering and Environmental Sciences, 23(1), 3-13.

StatSoft (2006). Elektroniczny Podręcznik Statystyki PL. Kraków. Retrieved from: https://www.statsoft.pl/textbook/stathome. html (accesed: 12.06.2018).

\section{Summary}

The control of the mass of an aggregates deliveries and its impact on the effectiveness of earthworks execution. The paper presents the method and tool which can be used to control the mass of aggregates deliveries under construction site conditions. The method based on statistics allows determining the optimal quantity of transports to be inspected, required to estimate the total sum of loose materials deliveries assuming estimation error and confidence level conditions. Inspection based on described method allows to improve the effectiveness of earthworks execution as well as gives the possibility to evaluate the quality of the supplier.

\section{Authors' address:}

Hubert Anysz, Wojciech Rogala

Politechnika Warszawska

Wydział Inżynierii Lądowej

ul. L. Kaczyńskiego 16, 00-636 Warszawa

Poland

e-mail: h.anysz@il.pw.edu.pl 